An analysis of public policy issues and how they affect MRS members and the materials community...

\title{
MRS Voices Concern over Appropriations Level Proposed for NSF
}

The U.S. House of Representatives Committee on Appropriations released a statement in July highlighting the FY 2005 VA-HUD Appropriations Bill. The bill designates $\$ 5.5$ billion to the National Science Foundation (NSF), which is $\$ 111$ million below last year and $\$ 278$ million below the request. Funding includes $\$ 4.2$ billion for research; \$208 million for research equipment; and $\$ 843$ million for education and human resources.

The leadership of the Materials Research Society (MRS) became concerned because the level of appropriations runs counter to a previous bill to double NSF funding by 2007, a bill which MRS strongly supported.

On August 16, 2004, MRS President Howard E. Katz sent a letter to James T. Walsh, Chair of the House Appropriations Committee and Alan B. Mollohan, Ranking Minority, House Appropriations Committee. Copies were sent to President George W. Bush Jr.; John H. Marburger III, Office of Science and Technology Policy; Josh B. Bolton, Office of Management and Budget; and Arden L. Bement Jr., Director, NSF. In addition, copies were sent to members of the House Appropriations Subcommittee and the House and Senate leadership.

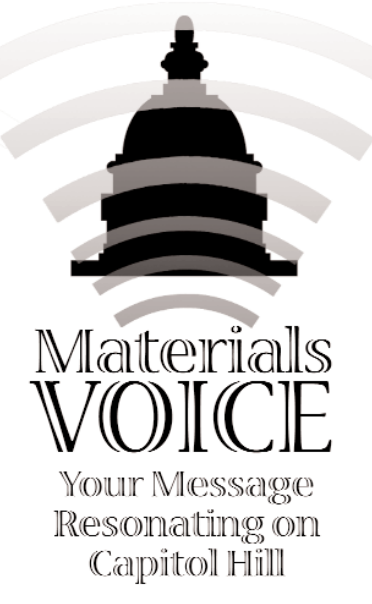

M|R|S

Materials Research Society

\section{Letter sent by the Materials Research Society}

August 16, 2004

Dear Chairman Walsh and Representative Mollohan:

The Materials Research Society is extremely concerned about the recent decisions reached by the House of Representatives' VA, HUD, and Independent Agencies Appropriation Subcommittee regarding the National Science Foundation (NSF). The NSF proposed mark of $\$ 5.47$ billion for FY05 is two percent less than the current FY04 NSF budget and is five percent less than the President's FY05 budget request for the National Science Foundation.

After many months of discussion and statements of commitment to the NSF to dramatically increase their budgets for the next five years, this appropriation does not reflect the bipartisan decisions made in Congress and the White House regarding commitment to doubling the NSF research base.

At a time of national crisis, it is vital that we continue to robustly fund our highestpriority long-term commitments. The National Science Foundation Authorization Act of 2002 (P.L. 107-368, "the doubling bill") provided significant increases in authorized funding for the NSF with the goal of doubling the NSF budget by FY2007. It is our belief that the intent of Congress in passing the doubling bill was to express national priority and resolve. Placing scientific programs and expertise at risk by reducing the President's budget request and dramatically lowering the goal of a five-year doubling of funding directly counteracts this intent.

NSF supports nearly 50\% of the non-medical basic research at American colleges and universities. It is a significant contributor to the progress in the physical sciences, mathematics, and engineering research funds in the US. It provides for the creation of a highly skilled and competitive science and engineering workforce through inquiry into new scientific frontiers. This work, and the educated people who join the workforce, are the backbone of the United States' scientific capabilities in national defense, economic security, homeland security, and healthcare.

The Materials Research Society represents 13,000 professional Ph.D. scientists and engineers working towards fundamental breakthroughs in electronics, aerospace, biomedical devices, nanotechnology, energy systems, and advanced computation and communication technologies.

On behalf of the Materials Research Society we join the voices of many others in the scientific community expressing concern over the appropriation level. We request that this decision be given priority reconsideration, with the aim of restoring NSF to its authorized doubling path, during the remaining weeks of the appropriation process and conference

Respectfully submitted,

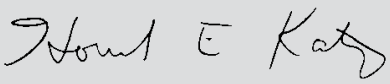

Howard Katz

MRS 2004 President

\section{Coming Soon}

\section{Materials Voice}

\section{A Web-based tool to ensure that your voice is heard on Capitol Hill!}

Tell your legislators why support of the physical sciences and science education is necessary... for national security, quality of life and a strong economy. 